
About IJMA [last updated July, $\left.1^{\text {st }}, 2021\right]$

$\checkmark$ International Journal of Medical Arts is the Official Journal of the Damietta Faculty of Medicine, AlAzhar University, Egypt

$\checkmark$ It is an International, Open Access, Double-blind, Peer-reviewed Journal

$\checkmark$ Published four times a year

$\checkmark$ The First Issue was published in July 2019

$\checkmark$ Published under the following license: Creative Commons Attribution-ShareAlike 4.0 International Public License (CC BY-SA 4.0). It had updated from the Creative Commons license [CC BY] in volume 2, Issue 4, October 2020 About IJMA

$\checkmark$ The Egyptian Knowledge Bank hosts the web site of IJMA

$\checkmark$ The Egyptian Knowledge Bank supports IJMA

$\checkmark$ IJMA follows the regulations of the International Committee of Medical Journal Editors

$\checkmark$ IJMA is indexed in the "Directory of Open Access Journals" [15 January 2021].

$\checkmark$ IJMA is indexed in JGate [29-6-2021]

$\checkmark$ IJMA is a member of the International Society of Managing and Technical Editors

$\checkmark$ Listed in "Index Copernicus", "Publons", "Academic resource index [ResearchBib]", "Electronics journal library", "Eurasian Scientific Journal Index", and "Citefactor"

$\checkmark$ IJMA introduced to the search engine [BASE] through DOAJ
Click image to reach the page

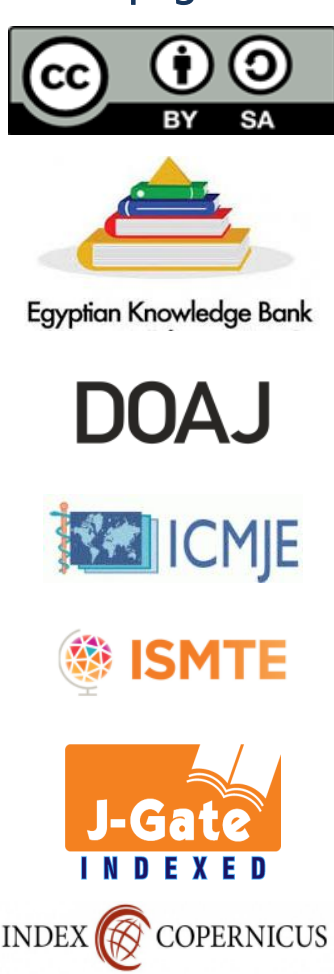

publons



\section{EZ3 \\ .}

ESJII

CiteFactor

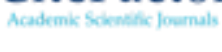

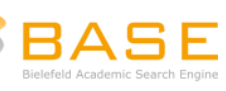




Available online at Journal Website
https://ijma.journals.ekb.eg/
Main subject [Obstetrics and Gynecology]

Original Article

\title{
Prevalence of Asymptomatic Bacteriuria among Pregnant Women At Damietta Governorate, Egypt
}

\author{
Eman Abdel-Hady Abdel-Aziz [1]; Walaa Mohamed Elbassioune [2]; Ahmed Abdeltawab [2]; Mohamed \\ Morshdy [3]
}

${ }^{1}$ Department of Obstetrics and Gynaecology, Mansoura Specialized Hospital, Ministry of Health, Egypt.

2 Department of Obstetrics and Gynaecology, Damietta Faculty of Medicine, Al-Azhar University, Egypt.

${ }^{3}$ Department of Microbiology and Immunology, Damietta Faculty of Medicine, Al-Azhar University, Egypt.

Corresponding author: Eman Abdel-Hady Abdel-Aziz

Email: emanabdelhady20@gmail.com

Submission date: June 05, 2021; Acceptance date: July 24, 2021

DOAJ

DOI: $10.21608 / \mathrm{ijma.2021.78877.1321}$

\section{ABSTRACT}

Background: Asymptomatic bacteriuria during pregnancy is a main health problem, which is related to an increased risk of maternal and fetal morbidity.

Aim of the Work: To estimate incidence of asymptomatic bacteriuria among pregnant females at Damietta Governorate, Egypt.

Patients and Methods: Five hundred randomly selected pregnant females attending antenatal care units at Damietta Governorate during the period July, first, 2019 - January 31st, 2021. All participants were subjected to full history taking, complete blood count as well as urine culture and bacterial count.

Result: A relatively high incidence of asymptomatic bacteriuria [13.8\%] was revealed among participants in whom the most causative organism was Escherichia coli. The rate was lower among pregnant women with a high social standard and during the first trimester. Maternal age, parity, education level, or hemoglobin level, on the other hand, had no significant relationship.

Conclusion: Screening of asymptomatic bacteriuria in pregnancy must be added to routinely antenatal care investigations and doing another studies on a wider scope are recommended.

Keywords: Asymptomatic Bacteriuria; Escherichia Coli; Pregnant Females; Urine Culture; Bacterial Count

This is an open-access article registered under the Creative Commons, ShareAlike 4.0 International license [CC BY-SA 4.0] [https://creativecommons.org/licenses/by-sa/4.0/legalcode.

Citation: Abdel-Aziz EA, Elbassioune WM, Abdeltawab A, Morshdy M. Prevalence of Asymptomatic Bacteriuria among Pregnant Women At Damietta Governorate, Egypt. IJMA 2020; 3[3]: July-September: 1700-1707. [DOI: 10.21608/ijma.2021.78877.1321].

${ }^{*}$ Main subject and any subcategories have been classified according to the research topic. 


\section{INTRODUCTION}

Asymptomatic bacteriuria in pregnancy is the existence of 100,000 or higher pathogens per millilitre of a clean catch mid-stream urine sample with no genitourinary tract symptoms ${ }^{[1]}$.

Many changes occur in female genito-urinary system, which can induce asymptomatic bacteriuria as renal pelvis and ureters dilation. Additionally, asymptomatic bacteriuria is induced by the bladder being displaced superiorly and anteriorly [2].

Many risk factors are related to asymptomatic bacteriuria during gestation such as low socio-economic stander, depressed immunity, DM, multiparty and anemia. Each of them has two folds increase in the rate of bacteriuria; preterm delivery and perinatal fetal death are the major ${ }^{[3]}$.

Asymptomatic bacteriuria can affect $2-10 \%$ of all pregnant females worldwide. Untreated bacteriuria during gestation is related to maternal and fetal hazards ${ }^{[4]}$.

No previous studies from Damietta [Egypt] dealt with the estimation of the prevalence of asymptomatic bacteriuria among pregnant women at Damietta governorate, so we want to estimate it.

\section{THE AIM OF THE WORK}

This study aimed to estimate the incidence of asymptomatic bacteriuria among pregnant women at Damietta Governorate, Egypt.

\section{PATIENTS AND METHODS}

This cross-sectional observational research was conducted during the period July, first, 2019 - January $31^{\text {st }}$, 2021 at the antenatal care units in Damietta Governorate [Egypt].

We included pregnant females [any parity] aged 20-40 years old, who were in their first or second trimester.

On the other side, We excluded any pregnant females with symptoms suggestive of vaginal infection [e.g., vaginal discharge, offensive odors, itching]; symptoms of urinary tract infections [e.g., dysuria, frequency, urgency]; use of antibiotic during last two weeks; known urinary tract malformations or chronic renal diseases; history of fever or chronic diseases [e.g., hypertension, Diabetes Mellitus, renal failure].

The calculated sample size was 384 participants using the following formula $=Z 2{ }^{*} P^{*}[1-P] / D^{2}$, in which $N$ denoted number of required subjects, $Z$ for the normal standard deviation [1.96], $P$ equals expected prevalence of asymptomatic bacteria in pregnant females [10\%].l, $Q$ equals [1-P] [The frequency of nonoccurrence of an event] and $\mathrm{D}$ for degree of precision [0.03\%] ${ }^{[5]}$.

The sample size was increased to 500 participants to increase the study power. " $\boldsymbol{N}=[\mathbf{1 . 9 6}]^{2} 0.1[\mathbf{1}-0.1] /[\mathbf{0 . 0 3}]$ ${ }^{2}=384^{\prime \prime}$.

A multistage random sample technique was conducted as the governorate is divided into five health districts. Three health districts were selected by simple random sampling. Within each health district and by simple random sampling, one antenatal care unit was selected giving a total of three antenatal care units.

At the selected antenatal care units, pregnant women were chosen randomly using 1:3:6:9... etc. All women matching inclusion criteria were recruited until the total target sample size was reached. There has been a relative equal distribution within each center of pregnant women's numbers.

\section{Each participant was subjected to the following:}

1. Full history taking including maternal age, social class assessment [by enquiring about the pregnant woman's and husband's occupations, monthly income, crowdness index "number of persons per room" [6]; education level [noneducated, primary school, preparatory school, secondary school, or college]; obstetric history [number of pregnancies, deliveries and abortions]; presence or absence of gestational diabetes.

2. Complete blood count: Two to three milli-liters of venous blood were collected from each pregnant woman into EDTA tubes. The blood sample was drawn from a peripheral vein using a disposable needle. An automated cell counter system was used to analyze the components of blood samples.

3. Urine culture and bacterial count: Urine samples were collected by employing the Midstream Clean Catch Specimens technique. Pregnant females were instructed to clean the urethral area and collected the urine midstream into a clean container. Urine specimens were examined within one hour of collection. CLED [cysteine-, lactose-, and electrolyte-deficient] agar, a differential culture medium was used for isolating and counting bacteria in urine from the suspected cases of urinary tract infection.

Significant bacteriuria was considered if a colony count 
$\geq 100,000$ per $\mathrm{mL}$ of urine and colony shape on CLED Agar utilized was as follows: [ $E$. Coli: Colonies that are opaque yellow with a slightly darker yellow core; Klebsiella species: Colonies that range in color from yellow to whitishblue and are very mucoid; Proteus species: Colonies of translucent blue; Pseudomonas aeruginosa: Colonies with a matted surface and a rough periphery are green; Enterococci: Small golden colonies with a diameter of about $0.5 \mathrm{~mm}$; Staphylococcus aureus: Colonies that are homogeneous in color and deep yellow; Coagulasenegative Staphylococci: Colonies that are pale yellow and more opaque than Enterococcus faecalis] [7].

\section{Ethical Consideration:}

The study protocol had been submitted for approval by Institutional Research Board, Damietta Faculty of Medicine, Al-Azhar University [IRB number: ADFM-03062019].

In addition, each participant had signed an informed written consent. Also, confidentiality and personal privacy had been respected through all stages of the study.

\section{Statistical Analysis:}

The information was analyzed using IBM SPSS version 20. To present quantitative data, the mean, standard deviations, and ranges were used. Qualitative variables, on the other hand, were given as numbers and percentages. When comparing two groups with qualitative data, the Chisquare test was utilized, and the Fisher exact test was used instead of the Chi-square test when the expected count in any cell was less than 5 .

For quantitative data having a parametric distribution, the Student's T-test was employed to compare two groups. The confidence interval was set to $95 \%$ and the margin of error accepted was set to $5 \%$. So, the p-value was considered significant at the level of $<0.05$ and highly significant at the level of $<0.01$.

\section{RESULTS}

All 500 pregnant females were tested for ASB in this research.

Table [1] showed that, the mean age of participants was $27.09 \pm 5.39$ years. $23.6 \%$ were primigravida; $15.4 \%$ had history of abortion; $87.8 \%$ were in the second trimester and $12.2 \%$ were in the first trimester; $50.8 \%$ completed the secondary school, $20 \%$ were completed collage and $12.8 \%$ were non-educated.

Of studied females, $51.8 \%$ were from moderate social class, and $26.6 \%$ were from high standard. In addition, $3 \%$ had gestational diabetes, and $75.6 \%$ had regular antenatal care. The mean hemoglobin was $10.31 \pm 0.09 \mathrm{gm} / \mathrm{dl}$.

Table [2] showed that $70.8 \%$ had sterile urine culture, $13.8 \%$ had significant and $9.6 \%$ had contamination.

Table [3] demonstrated that $68 \%$ had E coli, $18.8 \%$ had staphylococcus aureus and $8.6 \%$ had Klebsialla and $4.3 \%$ had Proteus species.

Table [1] shows the participants' sociodemographic data as well as its relation with positive cultures

\begin{tabular}{|c|c|c|c|}
\hline Character & $\begin{array}{c}\text { Frequency } \\
{[n=500]}\end{array}$ & $\begin{array}{c}\text { Positive culture } \\
{[n=69]}\end{array}$ & $\mathbf{P}$ \\
\hline Age [Mean $\pm S D$ ] & $27.09 \pm 5.39$ & $26.33 \pm 5.37$ & 0.0202 \\
\hline $\begin{array}{l}\text { Gravidity } \\
\text { Primigravida } \\
\text { Gravida two } \\
\text { Gravida three } \\
\text { Gravida four } \\
\text { Gravida five } \\
\text { Gravida six } \\
\text { Gravida seven }\end{array}$ & $\begin{array}{c}118[23.6 \%] \\
144[28.8 \%] \\
135[27 \%] \\
75[15 \%] \\
17[3.4 \%] \\
8[1.6 \%] \\
3[.06 \%]\end{array}$ & $\begin{array}{c}14[20.3 \%] \\
20[29 \%] \\
19[27.5 \%] \\
11[15.9 \%] \\
2[2.9 \%] \\
3[4.3 \%] \\
0[0 \%]\end{array}$ & 0.712 \\
\hline $\begin{array}{l}\text { Abortion } \\
\text { Yes } \\
\text { No }\end{array}$ & $\begin{array}{c}77[15.4] \\
423[84.6]\end{array}$ & $\begin{array}{l}56[81.2] \\
13[18,2]\end{array}$ & 0.116 \\
\hline $\begin{array}{l}\text { Gestational age } \\
\text { First trimester } \\
\text { Second trimester }\end{array}$ & $\begin{array}{c}61[12.2 \%] \\
439[87.8 \%]\end{array}$ & $\begin{array}{l}19[27.5 \%] \\
50[72.5 \%]\end{array}$ & 0.001 \\
\hline $\begin{array}{l}\text { Educational level } \\
\text { Non-educated } \\
\text { Primary school } \\
\text { Preparatory school } \\
\text { Secondary school } \\
\text { Collage }\end{array}$ & $\begin{array}{c}64[12.8 \%] \\
40[8 \%] \\
42[8.4 \%] \\
254[50.8 \%] \\
100[20 \%]\end{array}$ & $\begin{array}{c}9[13 \%] \\
9[13 \%] \\
10[14.5 \%] \\
30[43.5 \%] \\
11[15.9 \%]\end{array}$ & 0.133 \\
\hline $\begin{array}{l}\text { Socioeconomic level } \\
\text { High } \\
\text { Moderate } \\
\text { Low }\end{array}$ & $\begin{array}{l}133[26.6 \%] \\
259[51.8 \%] \\
108[21.6 \%]\end{array}$ & $\begin{array}{c}12[17.4 \%] \\
40[58 \%] \\
17[24.6 \%]\end{array}$ & 0.008 \\
\hline $\begin{array}{l}\text { Gestational diabetes } \\
\text { Present } \\
\text { Absent }\end{array}$ & $\begin{array}{c}15[3 \%] \\
485[97 \%]\end{array}$ & $\begin{array}{c}4[5.8 \%] \\
65[94.2 \%]\end{array}$ & 0.151 \\
\hline $\begin{array}{l}\text { Regular antenatal care } \\
\text { Yes } \\
\text { No }\end{array}$ & $\begin{array}{l}378[75.6 \%] \\
122[24.4 \%]\end{array}$ & $\begin{array}{l}23[33.3 \%] \\
46[66.7 \%]\end{array}$ & 0.05 \\
\hline Hemoglobin level & $10.31 \pm 0.09$ & $10.49 \pm 0.095$ & 0.175 \\
\hline
\end{tabular}

Table [2]: Results of urine culture

\begin{tabular}{|l|c|c|}
\hline & No & $\%$ \\
\hline Sterile & 354 & $70.8 \%$ \\
\hline Significant & 69 & $13.8 \%$ \\
\hline Contamination & 48 & $9.6 \%$ \\
\hline Insignificant & 29 & $5.8 \%$ \\
\hline
\end{tabular}

Table [3]: Organisms in culture of cases with significant bacteriuria

\begin{tabular}{|l|c|c|}
\hline & $\begin{array}{c}\text { No. } \\
{[\mathrm{n}=69]}\end{array}$ & $\%$ \\
\hline E.coli & 47 & $68 \%$ \\
\hline Staph aurus & 13 & $18.8 \%$ \\
\hline Klebsialla & 6 & $8.6 \%$ \\
\hline Proteus spp & 3 & $4.3 \%$ \\
\hline
\end{tabular}




\section{DISCUSSION}

Asymptomatic bacteriuria in pregnancy is a main health problem, which is related to an increased risk of maternal and fetal morbidity. Routinely screening for asymptomatic bacteriuria during gestation is recommended by most European and North American clinical practice guidelines ${ }^{[8]}$.

The worldwide incidence of asymptomatic bacteriuria during gestation ranges from $2-10 \%$ in all pregnant women. However, the incidence estimates markedly vary between studies. A number of socio-demographic risk factors of asymptomatic bacteriuria during gestation have been reported ${ }^{[9]}$. However, there is a paucity of studies on the incidence and risk factors of asymptomatic bacteriuria in pregnancy in Egypt.

Our work carried out to estimate the frequency and risk factors, particularly sociodemographic, of asymptomatic bacteriuria among pregnant females at Damietta Governorate [Egypt]. Participant's main age in our work was $27.1 \pm 5.39$ years. This is comparable to the mean age of participants in previous studies ${ }^{[10-14]}$.

However, some studies included participants with higher mean age, such as $32 \pm 5$ years in Fong et al. [15] research while others included participants with lower mean age, such as $24.3 \pm 4.6$ years in Ayoyi et al. [16] research. The variation could be attributed to the differences in the inclusion criteria as well as sociodemographic, geographic, and cultural differences among studies.

The incidence of asymptomatic bacteriuria in our work is $13.8 \%$. Moreover, results of urine culture showed that contamination and insignificant results in $9.6 \%$ and $5.8 \%$ of cases, respectively. In pregnancy, there are many structural and functional changes in urinary system, which can lead to asymptomatic bacteriuria as renal pelvis and ureters dilation, and the bladder is moved superiorly and anteriorly. The main cause of hydroureter and hydronephrosis is mechanical compression from the enlarged uterus, but progesterone-induced smooth muscle relaxation that can reduce peristalsis of the ureters, urinary stasis and higher bladder capacity. Differential $\mathrm{pH}$ and osmolality in the urine, along with glycosuria and aminoaciduria caused by pregnancy, can promote organisms to grow $[17,18]$.

Our findings are similar to those of a few previous studies. In a cross-sectional study on 1800 pregnant women during the second trimester in Bangladesh, the frequency of asymptomatic bacteriuria was $12 \%$ [19].

The incidence was $10.0 \%$ in a research on 360 Thai pregnant females ${ }^{[20]}$ and $10.6 \%$ by a Nigerian research [21]
In addition, in a recent systematic review and metaanalysis that involved 20 studies and 15108 pregnant women, the all rate of asymptomatic bacteriuria was estimated to be $13 \%$ in Iran [22].

In an Egyptian research on 171 pregnant women, 10\% had asymptomatic bacteriuria [13].

More recently, in a research on 715 Indonesian pregnant females, $10.2 \%$ of them had asymptomatic bacteriuria ${ }^{[8]}$.

However, some other studies found a higher incidence of asymptomatic bacteriuria in pregnancy. In studies from Nigeria, Oli et al. ${ }^{[23]}$ study on 357 pregnant women showed that $18.2 \%$ had asymptomatic bacteriuria.

In Izuchukwu et al. [24] work on 220 Nigerian pregnant females, the incidence of asymptomatic bacteriuria was $29.5 \%$. Another Nigerian research on 473 pregnant females found that $28.8 \%$ of them have asymptomatic bacteriuria ${ }^{225]}$.

Last, Oladeinde et al. [26] study, on 2020 pregnant women, reported a high frequency of asymptomatic bacteriuria of $55 \%$.

In Tadesse et al. [27] study on 244 Ethiopian pregnant women, the frequency of asymptomatic bacteriuria was $18.8 \%$. Another recent study from Ethiopia on 281 pregnant females showed an incidence of $19.9 \%$ [14].

In a Taiwanese study on 1187 pregnant women during the first trimester, the frequency of asymptomatic bacteriuria was $21.3 \%$ [28].

A Kenyan study on 1020 pregnant women showed a frequency of asymptomatic bacteriuria of $21.5 \%$ [16].

In Rohini et al. ${ }^{[29]}$ study on 200 Indian pregnant women, $30.5 \%$ of them had asymptomatic bacteriuria. On the other side, some studies reported a lower incidence of asymptomatic bacteriuria among pregnant women than that in our work.

In Aminu and Aliyu ${ }^{[12]}$ study on 200 Nigerian pregnant women, $9 \%$ had asymptomatic bacteriuria.

In a study on 600 pregnant females from Nepal, the incidence of asymptomatic bacteriuria was $8.7 \%$ [30]. Sujatha and Nawani [31] study on 300 Indian pregnant women revealed an incidence of asymptomatic bacteriuria of $7.3 \%$. A research from Ghana on 220 pregnant women showed that $7.3 \%$ of them had asymptomatic bacteriuria [32].

In another study from Ghana on 274 pregnant women, 
the incidence of asymptomatic bacteriuria was $5.5 \%$ [33].

In a study 4283 pregnant women from Netherland screened between 16 and 22 weeks' gestation, 5.8\% had asymptomatic bacteriuria [34].

In a study from Cameroon on 354 pregnant women, $5.7 \%$ of them had asymptomatic bacteriuria [35]. In a study from Bangladesh on 4242 pregnant women, the incidence of asymptomatic bacteriuria was $4.5 \%$ [36].

The incidence of asymptomatic bacteriuria among 170 pregnant women [during the second and third trimester] from Bruni Darussalam was 4.1\% [37]. In an Indian study on 107 pregnant women, asymptomatic bacteriuria was found in $3.2 \%$ of them ${ }^{[38] \text {. }}$

A study from Hong Kong on 1537 pregnant women [87\% were in the first trimester] showed asymptomatic bacteriuria in $2 \%$ of cases [15].

Other studies also showed a low incidence of asymptomatic bacteriuria among pregnant females, such as $3.6 \%$ reported in Sri Lanka ${ }^{[4]}, 1.9 \%$ in the Philippines ${ }^{[39]}$ and $1.7 \%$ in Saudi Arabia ${ }^{[10]}$.

Changes in asymptomatic bacteriuria incidence between and within nations could be due to differences in demographic factors such as age, parity, socioeconomic status, and cultural and religious attitudes linked to personal hygiene and sexual contact.

They could also be attributable to differences in the screening tests used or the study's environment [primary care, community-based, or hospitals] [urine dipstick, microscopy, and culture]. Last, this may be related to the design of studies [prospective or retrospective] [8, 10,37].

In the present work, the identified etiological microorganisms in urine culture were Escherichia coli [68\%], Staphylococcus aureus [18.8\%], Klebsiella [8.6\%], and Proteus [4.3\%]. In both pregnant and non-pregnant females, the etiologic factors that cause bacteriuria are the same. The female urethra, which is relatively short is commonly colonized by organisms from the gastrointestinal system. Escherichia coli is the most prevalent bacteria that causes bacteriuria, both symptomatic and asymptomatic, which accounts about $70-90 \%$ of isolates $[13,17,35]$.

Our results are consistent with most previous studies, in which Escherichia coli was the most commonly identified etiological factor of asymptomatic bacteriuria during gestation $[8,13,19,29,32]$. However, some studies found that is the commonest causative pathogen of asymptomatic bacteriuria in pregnant women is Klebsiella [12, 24, 37, 38].

Other studies found that Staphylococcus aureus is the commonest causative pathogen of asymptomatic bacteriuria in pregnancy $[27,40]$.

The differences could be attributed to the variable settings of collection [e.g., antenatal care units vs. hospitals and possible catheterized patients], presence of predisposing factors, and prevailing microorganisms in different settings.

No significant relationship between age and the prevalence of asymptomatic bacteriuria in our work. Our results agree with some previous studies that showed no significant relationship between the incidence of asymptomatic bacteriuria and age $[13,15,20,26,27,30,35]$. However, some studies reported a higher incidence of asymptomatic bacteriuria in certain age groups.

In Fong et al. [15] study, the highest incidence of asymptomatic bacteriuria was found among pregnant women aged $\geq 40$ years. Turpin et al. [32] reported that the highest age-specific prevalence of asymptomatic bacteriuria is $35-39$ year-old.

Labi et al. [33] and Izuchukwu et al. [24] studies showed a higher incidence of asymptomatic bacteriuria among pregnant women aged 30-34 years. In Kehindo et al. ${ }^{[25]}$ and Rohini et al. [29] studies, asymptomatic bacteriuria was most common among pregnant women of 25- 30 year's age group.

Another study reported the highest incidence in the age group between 21-30 years [31].

Last, Edae et al. [14] reported the highest prevalence in pregnant females between 18-26 years. It has been thought that increasing maternal age is associated with a higher prevalence of asymptomatic bacteriuria during gestation. This could be explained by the fact that when a mother's age increases, so does her parity, which is a risk factor for asymptomatic bacteriuria. However, some studies reported a significant association between a higher incidence of asymptomatic bacteriuria and lower maternal age ${ }^{[41]}$.

In our work, there was no significant association between the incidence of asymptomatic bacteriuria and hemoglobin level. This generally agrees with previous studies [12-14, 20, 24].

The present study demonstrated no significant association between the incidence of asymptomatic bacteriuria and either gravidity or parity. 
These results are in accordance with some studies, which showed no significant difference in the incidence of asymptomatic bacteriuria with parity $[13-15,20,30,32,33,35,40,41]$.

However, other studies reported a significant association between the incidence of asymptomatic bacteriuria and increasing parity $[12,21,26,29,42]$.

High parity can cause the pelvic organs to descend and the urethral orifice to enlarge, influencing the ascent of microorganisms [21].

This study showed no significant association between the frequencies of asymptomatic bacteriuria and history of previous abortions. This generally agrees with previous studies $[10,11,25]$.

Our study showed a statistically significant association between the frequency of asymptomatic bacteriuria and social standard. Pregnant women with high social standards had a lower incidence of asymptomatic bacteriuria. Indeed, the incidence of asymptomatic bacteriuria in pregnancy is closely related to socioeconomic status.

A study has reported that the incidence of asymptomatic bacteriuria was $2 \%$ in non-indigent compared to $6.5 \%$ of indigent pregnant women ${ }^{[41]}$.

In Aminu \& Aliyu [12] study, females with lower socioeconomic classes had higher incidence of asymptomatic bacteriuria in pregnancy. However, some studies showed no significant association between the incidence of asymptomatic bacteriuria and socioeconomic level [13].

The current study found no significant association between the frequency of asymptomatic bacteriuria during gestation and education level. This is consistent with findings of some previous studies $[13,15,25,30,33,40,41]$. However, some other studies reported a significant association between a higher frequency of asymptomatic bacteriuria in gestation and a lower education level [20,35].

In Oli et al. [23] study, women that had only primary education had the highest incidence [27.50\%] while those that had tertiary education had the least prevalence [21.10\%].

It is believed that improved hygiene that goes with a higher level of education is responsible for the drop in the frequency of bacteriuria in these studies $[20,35]$.

In this study, $3 \%$ of pregnant females had gestational diabetes mellitus [DM]. There was a tendency for a higher incidence of asymptomatic bacteriuria among pregnant women with gestational DM, although this didn't reach a statistically significant level. It has been traditionally thought that DM is associated with an increased incidence of asymptomatic bacteriuria and urinary tract infection. However, some studies showed no statistically significant difference in the frequency of asymptomatic bacteriuria between pregnant females with and without diabetes mellitus or gestational diabetes mellitus $[14,43,44]$.

The variation could be attributed to the differences in the inclusion criteria as well as gestational age of participants.

Our study showed that the incidence of asymptomatic bacteriuria was significantly higher in the first trimester than the second trimester.

Our results agree with Sujatha and Nawani. ${ }^{31]}$ Study. The higher incidence of asymptomatic bacteriuria in the first trimester could be a result of underlying asymptomatic urinary infection before pregnancy ensued or at the onset of pregnancy. However, some studies reported a higher incidence of asymptomatic bacteriuria during the second trimester $[25,45,46]$.

Other studies showed that asymptomatic bacteriuria is most common during the third trimester ${ }^{[23,26,29]}$.

Finally, other studies showed no statistically significant relationship between the incidence of asymptomatic bacteriuria and gestational age [11,13-15,20,21,27,33,35,40,41].

The discrepancy among studies could be related to different inclusion criteria. For example, our study included only women in the first and second trimester, while, for example, in Abdel-Aziz et al. ${ }^{[13]}$ study, $76 \%$ of participants were in the third trimester. Moreover, other confounding factors may play an important role.

In the present study, there was no significant association between the incidence of asymptomatic bacteriuria and antenatal care, which agrees with Edae et al. ${ }^{[14]}$ no significant association. However, other studies showed that the incidence of asymptomatic bacteriuria is higher in pregnant women who had irregular antenatal care. Maternal behaviors related to the risk of urinary infections are more frequent among women with irregular antenatal care ${ }^{[47]}$.

The current study has some limitations. First, this is a single-center study, which included participants from Damietta Governorate; the participants may not be representatives for the entire Egyptian population. Future wider scale and multicenter studies are recommended. Second, the study included pregnant females in only the first and second trimesters; we have no information on the 
occurrence of asymptomatic bacteriuria in the third trimester. Third, the present study didn't evaluate some factors that might affect the occurrence of asymptomatic bacteriuria during pregnancy, such as sexual activity, direction of genital washing, history of urinary catheterization, history of urinary tract infections. Fourth, our study didn't study the obstetric and perinatal outcome of asymptomatic bacteriuria and the beneficial effect of treatment. Last, although the sample size was calculated for the occurrence of asymptomatic bacteriuria, it might be inadequate to show a statistically significant difference when comparing groups with smaller numbers.

\section{Conclusion}

A relatively high incidence of asymptomatic bacteriuria [13.8\%] was revealed among participants in whom the most causative organism was Escherichia coli. The prevalence was lower among pregnant women with a high social standard and during the first trimester. Maternal age, parity, education level, or hemoglobin level, on the other hand, had no significant relationship.

Financial and Non-financial Relationships and Activities of Interest: None to be declared

\section{REFERENCES}

1. Fatima N, Ishrat S. Frequency and risk factors of asymptomatic bacteriuria during pregnancy. J Coll Physicians Surg Pak. 2006 Apr; 16[4]:273-5. [PMID: 16624191].

2. Lallar M, Haq A, Nandal R. Asymptomatic bacteriuria predisposing factors and correlation with preterm labor in low resource settings. Int J Reprod, Contracep, Obstetr Gynecol. 2017; 3[2]: 403-408. [DOI: 10.5455/2320-1770.jijcog20140624]

3. Perera J, Randeniya C, Perera P, Gamhewage N, Jayalatharchchi R. Asymptomatic bacteriuria in pregnancy: prevalence, risk factors and causative organisms. Sri Lankan J Infect Dis. 2012; 2[1]: 4246. [DOI: 10.4038/sljid.v2i1.3810].

4. Schnarr J, Smaill F. Asymptomatic bacteriuria and symptomatic urinary tract infections in pregnancy. Eur J Clin Invest. 2008 Oct; 38 Suppl 2:50-7. [DOI: 10.1111/j.1365-2362.2008.02009.x].

5. El-Gilany A, El-Wehady A, El-Wasify M. Updating and validation of the socioeconomic status scale for health research in Egypt. East Mediterr Health J. 2012 Sep; 18[9]:962-8. [DOI: 10.26719/ 2012. 18.9.962]

6. Mignini L, Carroli G, Abalos E, Widmer M, Amigot S, Nardin JM, et al; World Health Organization Asymptomatic Bacteriuria Trial Group. Accuracy of diagnostic tests to detect asymptomatic bacteriuria during pregnancy. Obstet Gynecol. 2009 Feb; 113[2 Pt 1]:346-52. [DOI: 10.1097/AOG.0b013e318194f109].

7. Rosana Y, Ocviyanti D, Halim M, Harlinda FY, Amran R, Akbar W, Billy M, Akhmad SRP. Urinary Tract Infections among Indonesian Pregnant Women and Its Susceptibility Pattern. Infect Dis Obstet Gynecol. 2020; 2020:9681632. [DOI: 10.1155/2020/9681632].

8. Moore A, Doull M, Grad R, Groulx S, Pottie K, Tonelli M, et al. Recommendations on screening for asymptomatic bacteriuria in pregnancy. CMAJ. 2018; 190[27]: E823-E830. [DOI: 10.1503/ cmaj.171325].

9. Al Sibiani SA. Asymptomatic bacteriuria in pregnant women in Jeddah, Western Region of Saudi Arabia: call for assessment. JKAU: Med Sci.2010; 17[1]: 29-42. [DOI:10.4197/med.17-1.4].

10. Moustafa MF, Makhlouf EM. Association between the hygiene practices for genital organs and sexual activity on urinary tract infection in pregnant women at women's Health Center, at Assiut University Hospital. J Am Sci.2012; 8: 515- 522.

11. Aminu KY, Aliyu UU. Asymptomatic Bacteriuria in Pregnant Women in the Antenatal Booking Clinic at Aminu Kano Teaching Hospital, Kano, Nigeria. Open J Obstet Gynecol. 2015; 5[1]: 56687. [DOI: 10.4236/ojog.2015.55042].

12. Abdel-Aziz Elzayat M, Barnett-Vanes A, Dabour MF, Cheng F. Prevalence of undiagnosed asymptomatic bacteriuria and associated risk factors during pregnancy: a cross-sectional study at two tertiary centres in Cairo, Egypt. BMJ Open. 2017; 7[3]: e013198. [DOI: 10.1136/bmjopen-2016-013198]

13. Edae M, Teklemariam Z, Weldegebreal F, Degu Abate D. Asymptomatic Bacteriuria among Pregnant Women Attending Antenatal Care at Hiwot Fana Specialized University Hospital, Harar, Eastern Ethiopia: Magnitude, Associated Factors, and Antimicrobial Susceptibility Pattern. Int J Microbiol. 2020; 1763931. [DOI: 10.1155/2020/1763931. eCollection 2020].

14. Fong S-Y, Tung C-W, Yu FN, Leung HH, Cheung JH. The Prevalence of Asymptomatic Bacteriuria in Pregnant Hong Kong Women. Hong Kong J Gynaecol Obstet Midwifery.2013; 13[1].

15. Ayoyi AO, Kikuvi G, Bii C, Kariuki S. Prevalence, etiology and antibiotic sensitivity profile of asymptomatic bacteriuria isolates from pregnant women in selected antenatal clinic from Nairobi, Kenya. Pan Afr Med J. 2017; 26: 41. [DOI: 10.11604/pam].2017.26.41. 10975. eCollection 2017].

16. Schnarr J, Smaill F: Asymptomatic bacteriuria and symptomatic urinary tract infections in pregnancy. Eur J Clin Invest. 2008; 38 Suppl 2: 50-57. [DOI: 10.1111/j.1365-2362.2008.02009.x].

17. Glaser AP, Schaeffer AJ. Urinary Tract Infection and Bacteriuria in Pregnancy. Urol Clinics North Am.2015; 42[4], 547-560. [DOI: 10.1016/j.ucl.2015.05.004]

18. Ullaah MA, Barman A, Siddique MA, Haque AK. Prevalence of asymptomatic bacteriuria and its consequences in pregnancy in a rural community of Bangladesh. Bangladesh Med Res Counc Bull.2007; 33[2]: 60- 64. [DOI: 10.3329/bmrcb.v33i2.1206].

19. Kovavisarach E, Vichaipruck M, Kanjarahareutai S.: Risk factors related to asymptomatic bacteriuria in pregnant women. $\mathrm{J}$ Med Assoc Thai.2009; 92[5]: 606-610.

20. Ojide CK, Wagbatsoma VA, Kalu El.: Asymptomatic bacteriuria among antenatal care women in a tertiary hospital in Benin, Nigeria. Niger J Exp Clin Biosci.2014; 2: 79-85.

21. Ghafari M, Baigi V, Cheraghi Z, Doosti-Irani A.: The Prevalence of Asymptomatic Bacteriuria in Iranian Pregnant Women: A Systematic Review and Meta- Analysis. PLoS One.2016; 11[6]: e0158031.

22. Oli AN, Okafor $\mathrm{Cl}$, Ibezim EC, Akujiobi CN, Onwunzo MC: The prevalence and bacteriology of asymptomatic bacteriuria among antenatal patients in Nnamdi Azikiwe University Teaching Hospital Nnewi; South Eastern Nigeria. Niger J Clin Pract.2010; 13[4]: 409412. 
23. Izuchukwu KE, Oranu EO, Bassey G, Orazulike NC.: Maternofetal outcome of asymptomatic bacteriuria among pregnant women in a Nigerian Teaching Hospital. Pan Afr Med J .2017; 27:69.

24. Kehinde AO, Adedapo KS, Aimaikhu CO, Odukogbe AT, Olayemi $\mathrm{O}$, Salako B. Significant bacteriuria among asymptomatic antenatal clinic attendees in Ibadan, Nigeria. Trop Med Health. 2011;39[3]: 73-76. [DOI: 10.2149/tmh.2011-02].

25. Oladeinde $\mathrm{BH}$, Omoregie $\mathrm{R}$, Oladeinde $\mathrm{OB}$ : Asymptomatic urinary tract infection among pregnant women receiving ante-natal care in a traditional birth home in Benin City, Nigeria. Ethiop J Health Sci.2015; 25[1]: 3-8. [DOI: 10.4314/ejhs.v25i1.2].

26. Tadesse E, Teshome M, Merid Y, Kibret B, Shimelis T. Asymptomatic urinary tract infection among pregnant women attending the antenatal clinic of Hawassa Referral Hospital, Southern Ethiopia. BMC Res Notes.2014; 7: 155. [DOI: 10. 1186/1756-0500-7-155].

27. Lai YJ, Hsu TY, Lan KC, Lin H, Ou C-Y, Hung-Chun Fu H-C, ChingChang Tsai C-C. Asymptomatic pyuria in pregnant women during the first trimester is associated with an increased risk of adverse obstetrical outcomes. Taiwan J Obstet Gynecol.2017; 56[2]: 192195. [DOI: 10.1016/j.tjog.2016.04.040].

28. Rohini UV, Reddy GS, Kandati J, Ponugoti M. Prevalence and associate risk factors of asymptomatic bacteriuria in pregnancy with bacterial pathogens and their antimicrobial susceptibility in a tertiary care hospital. Int J Reprod Contracept Obstet Gyneco.2017; 6[2]: 558-562.

29. Thakur A, Baral R, Basnet P, Rai R, Agrawal A, Regmi MC, Uprety DK. Asymptomatic bacteriuria in pregnant women. JNMA J Nepal Med Assoc.2013; 52[192]: 567-570.

30. Sujatha R. and Nawani M. Prevalence of asymptomatic bacteriuria and its antibacterial susceptibility pattern among pregnant women attending the antenatal clinic at Kanpur, India. J Clin Diagn Res. 2014; 8[4]: DC01-DC3. [DOI: 10.7860/JCDR/2014/6599.4205].

31. Turpin C, Minkah B, Danso K, Frimpong E. Asymptomatic bacteriuria in pregnant women attending antenatal clinic at komfo anokye teaching hospital, Kumasi, Ghana. Ghana Med J.2007; 41[1]: 26-29. [PMID: 17622336].

32. Labi AK, Yawson AE, Ganyaglo GY, Newman MJ. Prevalence and Associated Risk Factors of Asymptomatic Bacteriuria in Ante-Natal Clients in a Large Teaching Hospital in Ghana. Ghana Med J.2015; 49 [3]: 154-158. [DOI: 10.4314/gmj.v49i3.5].

33. Kazemier BM, Koningstein FN, Schneeberger C, Ott A, Bossuyt PM, de Miranda E, et al. Maternal and neonatal consequences of treated and untreated asymptomatic bacteriuria in pregnancy: a prospective cohort study with an embedded randomized controlled trial. Lancet Infect Dis. 2015; 15[11]: 1324-1333. [DOI: 10.1016/S1473-3099 [15]00070-5].

34. Tchente NC, Okalla EC, Nouwe CC, Ebong EC, Nana NT, Mboudou E. Clinical presentation, risk factors and pathogens involved in bacteriuria of pregnant women attending antenatal clinic of 3 hospitals in a developing country: a cross sectional analytic study. BMC Pregnancy Childbirth 2019; 9[1]: 143. [DOl: 10. 1186/s12884-019-2290-y].
35. Lee AC, Mullany LC, Koffi AK, Rafiqullah I, Khanam R, Folger LV, et al. Urinary tract infections in pregnancy in a rural population of Bangladesh: population-based prevalence, risk factors, etiology, and antibiotic resistance. BMC Pregnancy Childbirth. 2019; 20[1]: 1. [DOI: 10.1186/s12884-019-2665-0].

36. Muharram SH, Ghazali SN, Yaakub HR, Abiola O. A preliminary assessment of asymptomatic bacteriuria of pregnancy in Brunei Darussalam. Malays J Med Sci.2014; 21[2]: 34-39. [PMID: 24876805].

37. Rajaratnam A, Baby NM, Kuruvilla TS, Machado S. Diagnosis of asymptomatic bacteriuria and associated risk factors among pregnant women in Mangalore, Karnataka, India. J Clin Diagn Res. 2014; 8[9]: OC23-OC25. [DOI: 10.7860/JCDR/2014/8537.4842].

38. Sescon NIC, Garingalao-Molina FD, Ycasiano CEJ, Saniel MC, Manalastas RM. Prevalence of Asymptomatic Bacteriuria and Associated Risk Factors in Pregnant Women. Phil J Microbiol Infect Dis. 2003; 32[2]: 63-69.

39. Onu FA, Ajah LO, Ezeonu PO, Umeora OU, Ibekwe PC, Ajah MI. Profile and microbiological isolates of asymptomatic bacteriuria among pregnant women in Abakaliki, Nigeria. Infect Drug Resist. 2015; 8: 231-235. [DOI: 10.2147/IDR.S87052. eCollection 2015].

40. Hazhir S. Asymptomatic bacteriuria in pregnant women. Urol J. 2007; 4[1]: 24-27. [PMID: 17514607].

41. Nisha AK, Etana AE, Tesso $H$. Prevalence of asymptomatic bacteriuria during pregnancy in Adama city, Ethiopia. Int J Microbiol Immunol Res.2015; 3: 58-63.

42. Mekapogu NP, Gundela S, Avula RD. Diabetes Mellitus has no Significant Influence on the Prevalence of Antenatal Asymptomatic Bacteriuria. J Clin Diagn Res.2016; 10[4]: DC16-DC20. [DOI: 10. 7860/JCDR/2016/14939.7632]

43. Schneeberger C, Erwich JJHM, van den Heuvel ER, Mol BWJ, Ott A, Geerlings SE. Asymptomatic bacteriuria and urinary tract infection in pregnant women with and without diabetes: Cohort study. Eur J Obstet Gynecol Reprod Biol.2018; 222: 176-181. [DOI: 10.1016/j.ejogrb.2017.12.013].

44. Sharma P. and Thapa L. Acute pyelonephritis in pregnancy: a retrospective study. Aust N Z J Obstet Gynaecol. 2007; 47: 313315.

45. Jassim ZM, Jabuk SI, Obaid MH. Asymptomatic bacteriuria and pyuria in pregnant women in Hilla city: causative agents and antibiotic sensitivity. J Babylon Univ.2013; 21[8]: 2754-2763.

46. Babic U, Opric D, Perovic M, Dmitrovic A, Mihailovi CS, Kocijancic $D$, et al. Influence of regularity of checkups during pregnancy on prevalence of asymptomatic bacteriuria and maternal behaviors regarding urinary infection prevention. Clin Exp Obstet Gynecol.2015; 42[2]: 208-211. [PMID: 26054121]. 

